\title{
Potential Common Key Genes Associated with Chronic Periodontitis and Low Birth Weight: A Case Control Study Using Bioinformatics Analysis of Pooled mRNA Expression Datasets
}

Asami Suzuki ( $\nabla$ nduh-a-suzuki@tky.ndu.ac.jp )

The Nippon Dental University Hospital at Tokyo https://orcid.org/0000-0002-6124-8363

Tetsuro Horie

The Nippon Dental University

Akihito Nakai

Nihon Ika Daigaku - Musashisakai Campus

Eriko Kikuchi

Nihon Medical School

Yukihiro Numabe

The Nippon Dental university

\section{Research article}

Keywords: Chronic periodontitis, Low birth weight, Differentially expressed genes, Biomarker candidates, Upstream regulators

Posted Date: June 22nd, 2020

DOI: https://doi.org/10.21203/rs.3.rs-35932/v1

License: (9) (i) This work is licensed under a Creative Commons Attribution 4.0 International License. Read Full License 


\section{Abstract}

Background: Chronic periodontitis (CP) is a multifactorial disease associated with many systemic diseases. However, the precise association between CP and low birth weight (LBW) remains unclear. Therefore, this study aimed to elucidate common differentially expressed genes (DEGs), biomarker candidates, and upstream regulators related to key genes between CP and LBW.

Methods: We investigated molecular relations and biomarker candidates using pooled microarray datasets of CP (GSE12484) and LBW (GSE29807) in the Gene Expression Omnibus (GEO). Datasets were analyzed for common DEGs using GEO2R, an Rbased web application for GEO data analysis. Common DEGs, biomarker candidates, and upstream regulators in DEGs between CP and LBW were analyzed using the Database for Annotation Visualization and Integrated Discovery (DAVID), Search Tool for the Retrieval of Interacting Genes (STRING), and QIAGEN's Ingenuity Pathway Analysis (IPA).

Results: Three significantly upregulated and 20 significantly downregulated common DEGs between CP and LBW were identified. Some biological processes and pathways of these downregulated genes were associated with the cell cycle. Biomarker candidates among common DEGs were proline-rich coiled-coil 2A (PPRC2A), topoisomerase (DNA) II alpha (TOP2A), neural cell adhesion molecule 1 (NCAM1), and calcium channel, voltage-dependent, alpha 2/delta subunit 3 (CACNA2D3). Many upstream regulators of these biomarker candidates were factors associated with inflammation, immunity, the cell cycle, and growth development, and were hormones related to pregnancy.

Conclusions: The results of this study suggest that PPRC2A, TOP2A, NCAM1, and CACNA2D3 are common biomedical key genes between CP and LBW. The expression states of these genes, which are related to inflammation, hormones, the cell cycle, and growth development, were common in both CP and LBW in blood. To the best of our knowledge, the relations of PPRC2A, TOP2A, and CACNA2D3 to CP and LBW are reported for the first time. Thus, in the bloodstream, inflammatory-related upstream regulators of these key genes may control gene expression associated with fetal growth, and conversely, changes in female hormones due to pregnancy may affect the progress of CP.

\section{Background}

Chronic periodontitis (CP) is characterized by chronic destructive inflammation in periodontal tissues, such as gingiva, cementum, periodontal ligament, and alveolar bone. CP is an inflammatory disease caused by multiple factors, such as immunological response, hormone-regulated gestation, oral bacterial infections, genetic factors, environmental factors, and systematic diseases. Recently, epidemiological studies have reported that CP is related to systemic diseases such as diabetes, rheumatism, cardiovascular disease, chronic kidney disease, premature birth, and low birth weight (LBW; LBW infants are those weighing $<2,500 \mathrm{~g}$ at birth). The mechanisms of CP development and progression are complex and have not been completely elucidated. In periodontology, it is important to carry out research on the associations between CP and these systemic diseases to elucidate the mechanisms of $\mathrm{CP}$ and identify potential targets for clinical treatment.

Offenbacher et al. first reported the association between CP and LBW in 1996 [1]. Subsequently, many studies were carried out on the association between CP and LBW. Although some epidemiological meta-analyses have reported associations between $\mathrm{CP}$ and LBW, the underlying molecular mechanisms remain unclear. The pathogenic bacterium of $\mathrm{CP}$ and chemical mediators produced by inflammation in gingiva were considered to penetrate into weak capillary blood vessels, and then to cord blood through the placenta [2-4]. Some researchers have reported that CP influences the development of LBW [5-22], whereas others have denied such an association [23-27]. Therefore, no consensus has been reached on the association between $\mathrm{CP}$ and LBW [28-31], and more studies are needed to address this issue. In this study, we focused on the molecular biological interaction between CP and LBW.

We devised a study to investigate the relation between CP and LBW using gene expression profiling in blood. Gene expression profiling is a powerful tool that can elucidate the mechanisms and relations between multifactorial diseases, such as $\mathrm{CP}$ and 
LBW. Analyzing pooled gene expression datasets with CP or LBW, even under different experimental conditions with different subjects, is useful for investigating common genetic factors.

Data sharing and the integration of pooled omics data to investigate the mechanisms of and relations with multifactorial diseases have received increasing attention as screening tools. The use of pooled microarray gene expression datasets is an effective method for reducing high-throughput hybridization costs and compensating for insufficient amounts of mRNA sampling [32-34]. Thus, the National Center for Biotechnology Information developed the Gene Expression Omnibus (GEO) to promote the pooling and sharing of publicly available transcriptomic data and facilitate biomedical research [35-49].

This study aimed to investigate the common genetic factors and relations between CP and LBW through a bioinformatics analysis of differentially expressed genes (DEGs) using pooled microarray datasets from the GEO database.

\section{Methods}

In this study, we used pooled microarray gene expression datasets from the public GEO database to investigate the common molecular factors of CP and LBW as screening tools.

\section{Selection Of Microarray Datasets From The Geo Database}

We selected datasets based on the experiential conditions of CP (GSE12484) and LBW (GSE29807) in the National Center for Biotechnology Information (NCBI) GEO database (http://www.ncbi.nlm.nih.gov/geo/). These datasets, which include more than two healthy controls/two diseased patients each, were selected based on the typical clinical condition. Samples from peripheral or umbilical cord blood were used, along with a microarray platform (GPL96: Affymetrix GeneChip ${ }^{\text {TM }}$ Human Genome U133A Array [HG-U133A] or GPL570: Affymetrix GeneChip ${ }^{\text {TM }}$ Human Genome U133 Plus 2.0 Array [HG-U133 Plus 2]) (Table 1).

Table 1

Summary of studies of CP and LBW

\begin{tabular}{|lll|}
\hline Disease & Chronic periodontitis & Low birth weight \\
\hline GEO dataset ID & GSE12484 & GSE29807 \\
\hline Platform & $\begin{array}{l}\text { GPL96: Affymetrix GeneChip }{ }^{\text {TM }} \text { Human } \\
\text { Genome U133A Array } \\
\text { (HG-U133A) }\end{array}$ & $\begin{array}{l}\text { GPL570: Affymetrix GeneChip }{ }^{\text {TM }} \text { Human } \\
\text { Genome U133 Plus 2.0 Array } \\
\text { (HG-U133 Plus 2) }\end{array}$ \\
\hline Sample & Peripheral blood & Umbilical cord blood \\
\hline $\begin{array}{l}\text { Number of healthy controls vs. } \\
\text { persons with disease }\end{array}$ & 2 vs. 2 & 4 vs. 8 \\
\hline Diabetes & No & No \\
\hline Smoking & No & No \\
\hline Other & $\begin{array}{l}\text { No systemic antibiotics or anti- } \\
\text { inflammatory drugs for 6 months }\end{array}$ & $\begin{array}{l}\text { No systemic antibiotics or anti- } \\
\text { inflammatory drugs for 6 months }\end{array}$ \\
\hline PubMed ID & 18832737 & No \\
\hline
\end{tabular}

\section{Identification Of Common Up/downregulated Differentially Expressed Genes (degs)}

The CP or LBW DEGs between patients and normal healthy controls were identified using GEO2R, an R-based web application for analyzing GEO data. A cutoff value of $\mathrm{p}<0.05$ and a $\mid \log$ Fold change $(\mathrm{Fc}) \mid>1$ were used. Common up/downregulated 


\section{Functional And Pathway Enrichment Analysis Of Common Degs}

The results of the functional enrichment analysis of common up- or downregulated DEGs based on the BP of GO, and pathway enrichment analyzed based on the KEGG and Reactome pathway using DAVID are shown in Tables 4-6.

Table 4

Biological processes $(\mathrm{BP})$ of downregulated DEGs $($ FDR $<0.05)$

\begin{tabular}{|c|c|c|c|c|c|}
\hline GO term ID & Term description & $\begin{array}{l}\text { Observed } \\
\text { gene count }\end{array}$ & $\begin{array}{l}\text { Background } \\
\text { gene count }\end{array}$ & FDR & $\begin{array}{l}\text { Matching proteins in } \\
\text { network }\end{array}$ \\
\hline Go:0010639 & $\begin{array}{l}\text { Negative regulation of organelle } \\
\text { organization }\end{array}$ & 5 & 333 & 0.0124 & $\begin{array}{l}\text { ADD2, NEK2, SLC35F6, } \\
\text { TOP2A, TTK }\end{array}$ \\
\hline GO:0022402 & Cell cycle process & 7 & 890 & 0.0124 & $\begin{array}{l}\text { CCNB2, CDKN1C, CENPA, } \\
\text { CEP76, NEK2, TOP2A, TTK }\end{array}$ \\
\hline GO:1903047 & Mitotic cell cycle process & 6 & 564 & 0.0124 & $\begin{array}{l}\text { CCNB2, CENPA, CEP76, } \\
\text { NEK2, TOP2A, TTK }\end{array}$ \\
\hline GO:1902850 & $\begin{array}{l}\text { Microtubule cytoskeleton } \\
\text { organization involved in mitosis }\end{array}$ & 3 & 94 & 0.0194 & CENPA, NEK2, TTK \\
\hline GO:0071459 & $\begin{array}{l}\text { Protein localization to } \\
\text { chromosome, centromeric region }\end{array}$ & 2 & 18 & 0.0222 & CENPA, TTK \\
\hline G0:0000086 & $\begin{array}{l}\text { G2/M transition of mitotic cell } \\
\text { cycle }\end{array}$ & 3 & 123 & 0.0262 & CCNB2, CEP76, NEK2 \\
\hline GO:0006779 & $\begin{array}{l}\text { Porphyrin-containing compound } \\
\text { biosynthetic process }\end{array}$ & 2 & 23 & 0.0262 & ABCB6, CPOX \\
\hline GO:0007143 & Female meiotic nuclear division & 2 & 28 & 0.0262 & TOP2A, TTK \\
\hline G0:0007346 & Regulation of mitotic cell cycle & 5 & 608 & 0.0262 & $\begin{array}{l}\text { CDKN1C, CEP76, NEK2, } \\
\text { TOP2A, TTK }\end{array}$ \\
\hline GO:0051304 & Chromosome separation & 2 & 25 & 0.0262 & TOP2A, TTK \\
\hline G0:0006778 & $\begin{array}{l}\text { Porphyrin-containing compound } \\
\text { metabolic process }\end{array}$ & 2 & 36 & 0.0327 & ABCB6, CPOX \\
\hline GO:0051726 & Regulation of cell cycle & 6 & 1129 & 0.0327 & $\begin{array}{l}\text { CCNB2, CDKN1C, CEP76, } \\
\text { NEK2, TOP2A, TTK }\end{array}$ \\
\hline G0:0033043 & $\begin{array}{l}\text { Regulation of organelle } \\
\text { organization }\end{array}$ & 6 & 1155 & 0.0344 & $\begin{array}{l}\text { ADD2, CEP76, NEK2, } \\
\text { SLC35F6, TOP2A, TTK }\end{array}$ \\
\hline G0:0015701 & Bicarbonate transport & 2 & 44 & 0.0403 & CA1, RHAG \\
\hline GO:0098813 & Nuclear chromosome segregation & 3 & 196 & 0.0403 & NEK2, TOP2A, TTK \\
\hline GO:0051301 & Cell division & 4 & 483 & 0.0486 & $\begin{array}{l}\text { CCNB2, CENPA, NEK2, } \\
\text { TOP2A }\end{array}$ \\
\hline G0:0051321 & Meiotic cell cycle & 3 & 214 & 0.0486 & NEK2, TOP2A, TTK \\
\hline
\end{tabular}


Table 5

KEGG pathway of downregulated DEGs $($ FDR $<0.05)$

\begin{tabular}{|llllll|}
\hline $\begin{array}{l}\text { KEGG pathway } \\
\text { ID }\end{array}$ & $\begin{array}{l}\text { Term } \\
\text { description }\end{array}$ & $\begin{array}{l}\text { Observed gene } \\
\text { count }\end{array}$ & $\begin{array}{l}\text { Background gene } \\
\text { count }\end{array}$ & FDR & $\begin{array}{l}\text { Matching proteins in } \\
\text { network }\end{array}$ \\
\hline hsa04110 & Cell cycle & 3 & 123 & 0.0077 & CCNB2, CDKN1C, TTK \\
\hline
\end{tabular}

Table 6

Common reactome pathway of downregulated DEGs $($ FDR $<0.05)$

\begin{tabular}{|c|c|c|c|c|c|}
\hline \#term ID & Term description & $\begin{array}{l}\text { Observed } \\
\text { gene count }\end{array}$ & $\begin{array}{l}\text { Background } \\
\text { gene count }\end{array}$ & FDR & $\begin{array}{l}\text { Matching proteins in } \\
\text { network }\end{array}$ \\
\hline $\begin{array}{l}\text { HSA- } \\
69278\end{array}$ & Cell cycle, mitotic & 6 & 483 & 0.00074 & $\begin{array}{l}\text { CCNB2, CDKN1C, CENPA, } \\
\text { CEP76, NEK2, TOP2A }\end{array}$ \\
\hline $\begin{array}{l}\text { HSA- } \\
1247673\end{array}$ & $\begin{array}{l}\text { Erythrocytes take up oxygen and } \\
\text { release carbon dioxide }\end{array}$ & 2 & 8 & 0.0015 & CA1, RHAG \\
\hline $\begin{array}{l}\text { HSA- } \\
68877\end{array}$ & Mitotic prometaphase & 4 & 190 & 0.0015 & $\begin{array}{l}\text { CCNB2, CENPA, CEP76, } \\
\text { NEK2 }\end{array}$ \\
\hline $\begin{array}{l}\text { HSA- } \\
1237044\end{array}$ & $\begin{array}{l}\text { Erythrocytes take up carbon dioxide } \\
\text { and release oxygen }\end{array}$ & 2 & 12 & 0.002 & CA1, RHAG \\
\hline $\begin{array}{l}\text { HSA- } \\
2565942\end{array}$ & $\begin{array}{l}\text { Regulation of PLK1 Activity at G2/M } \\
\text { transition }\end{array}$ & 3 & 85 & 0.002 & CCNB2, CEP76, NEK2 \\
\hline $\begin{array}{l}\text { HSA- } \\
380259\end{array}$ & $\begin{array}{l}\text { Loss of Nlp from mitotic } \\
\text { centrosomes }\end{array}$ & 2 & 68 & 0.0229 & CEP76, NEK2 \\
\hline $\begin{array}{l}\text { HSA- } \\
8854518\end{array}$ & AURKA activation by TPX2 & 2 & 71 & 0.0229 & CEP76, NEK2 \\
\hline $\begin{array}{l}\text { HSA- } \\
380270\end{array}$ & $\begin{array}{l}\text { Recruitment of mitotic centrosome } \\
\text { proteins and complexes }\end{array}$ & 2 & 79 & 0.024 & CEP76, NEK2 \\
\hline $\begin{array}{l}\text { HSA- } \\
380320\end{array}$ & $\begin{array}{l}\text { Recruitment of NuMA to mitotic } \\
\text { centrosomes }\end{array}$ & 2 & 91 & 0.0276 & CEP76, NEK2 \\
\hline $\begin{array}{l}\text { HSA- } \\
5620912\end{array}$ & $\begin{array}{l}\text { Anchoring of the basal body to the } \\
\text { plasma membrane }\end{array}$ & 2 & 96 & 0.0287 & CEP76, NEK2 \\
\hline $\begin{array}{l}\text { HSA- } \\
382551\end{array}$ & Transport of small molecules & 4 & 706 & 0.0319 & $\begin{array}{l}\text { ABCB6, ADD2, CA1, } \\
\text { RHAG }\end{array}$ \\
\hline $\begin{array}{l}\text { HSA- } \\
2500257\end{array}$ & $\begin{array}{l}\text { Resolution of sister chromatid } \\
\text { cohesion }\end{array}$ & 2 & 118 & 0.0381 & CCNB2, CENPA \\
\hline
\end{tabular}

Common upregulated DEGs were not significantly enriched in BP, KEGG, or the Reactome pathway. Common downregulated DEGs were significantly enriched in BP, KEGG, and the Reactome pathway (Tables 4-6). Predominantly, common downregulated DEGs were related to the cell cycle and metabolic processes in BP, and to the cell cycle, cell composition, erythrocyte function, and transport pathways for small molecules in KEGG and the Reactome pathway.

\section{Constructed Protein-protein Interaction (ppi) Networks Of Common Degs}

Constructed PPI networks of common up- and downregulated genes were identified using the Search Tool for the Retrieval of Interacting Genes (STRING) (https://string-db.org/cgi/about.pl). 


\section{Elucidation Of Common Molecular Biomarker Candidates}

Common molecular biomarker candidates between CP and LBW were identified using IPA software (Table 7). Biomarker candidates are used to identify disease states such as diagnosis, efficacy, disease progression, and prognosis. Proline-rich coiled-coil 2A (PRRC2A) was a significant common upregulated DEG, whereas calcium channel, voltage-dependent, alpha 2/delta subunit 3 (CACNA2D3), neural cell adhesion molecule 1 (NCAM1), and TOP2A were significant common downregulated DEGs.

Table 7

Common molecular biomarker candidates for diagnosis, prognosis, and other processes

\begin{tabular}{|c|c|c|c|}
\hline $\begin{array}{l}\text { Gene } \\
\text { symbol }\end{array}$ & Entrez gene name & $\begin{array}{l}\text { Up- or } \\
\text { downregulated } \\
\text { DEG }\end{array}$ & $\begin{array}{l}\text { Biomarker } \\
\text { application(s) }\end{array}$ \\
\hline IFIT2 & Interferon-induced protein with tetratricopeptide repeats 2 & & Diagnosis \\
\hline TOP2A & DNA topoisomerase II alpha & $\begin{array}{l}\text { Downregulated } \\
\text { DEG }\end{array}$ & $\begin{array}{l}\text { Diagnosis, efficacy, } \\
\text { prognosis, response } \\
\text { to therapy }\end{array}$ \\
\hline ATF6 & Activating transcription factor 6 & & Efficacy \\
\hline TNFSF10 & TNF superfamily member 10 & & Efficacy \\
\hline NCAM1 & Neural cell adhesion molecule 1 & $\begin{array}{l}\text { Downregulated } \\
\text { DEG }\end{array}$ & $\begin{array}{l}\text { Efficacy, prognosis, } \\
\text { unspecified } \\
\text { Application }\end{array}$ \\
\hline CACNA2D3 & Calcium channel, voltage-dependent, alpha $2 /$ delta subunit 3 & $\begin{array}{l}\text { Downregulated } \\
\text { DEG }\end{array}$ & Prognosis \\
\hline GART & $\begin{array}{l}\text { Phosphoribosylglycinamide formyltransferase, } \\
\text { phosphoribosylglycinamide synthetase, } \\
\text { phosphoribosylaminoimidazole synthetase }\end{array}$ & & Prognosis, safety \\
\hline PRRC2A & Proline-rich coiled-coil 2A & $\begin{array}{l}\text { Upregulated } \\
\text { DEG }\end{array}$ & Safety \\
\hline PVT1 & Pvt1 oncogene & & Safety \\
\hline
\end{tabular}

\section{Analysis Of Upstream Regulators Of Dominant Common Degs}

Upstream regulators of common DEGs were analyzed using comparison analysis in IPA software. DEGs were uploaded into the IPA software, and genetic networks were analyzed in the Ingenuity Knowledge Base. We also analyzed the functional annotations of upstream regulators.

\section{Results}

We investigated common DEGs, BP and pathway analyses, biomarker candidates, and upstream regulators between $\mathrm{CP}$ and LBW through gene expression profiling of the GEO datasets.

\section{Identification Of Common Degs}

Common DEGs were identified from among respective DEGs investigated using GEO2R, and genes involved in the pathogenesis of CP and LBW were elucidated. Three significantly upregulated and 20 significantly downregulated common DEGs between CP and LBW were identified, as shown in Tables 2 and $3(p<0.05,|\log F c|>1)$. Venn diagrams representing the overlap of DEGs between CP (GSE12484) and LBW (GSE29807) are shown in Fig. 1. 
Table 2

Significant common upregulated DEGs $(p<0.05, \log F C>1)$

\begin{tabular}{|lllllll|}
\hline Gene symbol & Gene title & Affy ID & \multicolumn{2}{ll}{ Chronic periodontitis } & \multicolumn{2}{l|}{ Low birth weight } \\
\hline & & & logFC & p-value & logFC & p-value \\
\hline PRRC2A & Proline-rich coiled-coil 2A & 208132_x_at & 1.447139 & 0.00284602 & 1.17 & 0.04361717 \\
\hline RPS2 & Ribosomal protein S2 & 217466_x_at & 1.6966286 & 0.04138839 & 2.38 & 0.0281293 \\
\hline SNORA64 & Small nucleolar RNA, H/ACA box 64 & 217466_x_at & 1.6966286 & 0.04138839 & 2.38 & 0.0281293 \\
\hline
\end{tabular}


Table 3

Significant common downregulated DEGs $(p<0.05, \log F C<-1)$

\begin{tabular}{|c|c|c|c|c|c|c|}
\hline \multirow{2}{*}{$\begin{array}{l}\text { Gene } \\
\text { symbol }\end{array}$} & \multirow[t]{2}{*}{ Gene title } & \multirow[t]{2}{*}{ Affy ID } & \multicolumn{2}{|c|}{ Chronic periodontitis } & \multicolumn{2}{|c|}{ Low birth weight } \\
\hline & & & $\log \mathrm{FC}$ & p-value & $\log F C$ & p-value \\
\hline ABCB6 & $\begin{array}{l}\text { ATP binding cassette subfamily B } \\
\text { member } 6\end{array}$ & 203192_at & $\overline{1} .0569106$ & 0.0431129 & $\overline{1.31}$ & 0.00294847 \\
\hline ADD2 & Adducin 2 & 205268_s_at & $\overline{1} .1046457$ & 0.00777222 & $\overline{1} .94$ & 0.00917617 \\
\hline ALDH6A1 & $\begin{array}{l}\text { Aldehyde dehydrogenase } 6 \text { family, } \\
\text { member A1 }\end{array}$ & 221590_s_at & $\overline{2} .2681268$ & 0.00798702 & $\overline{1} .26$ & 0.03233938 \\
\hline CA1 & Carbonic anhydrase 1 & 205950_s_at & $\overline{-} 1.5793517$ & 0.02485654 & $\overline{1} \cdot 63$ & 0.04056291 \\
\hline CACNA2D3 & $\begin{array}{l}\text { Calcium channel, voltage-dependent, } \\
\text { alpha } 2 \text { /delta subunit } 3\end{array}$ & 219714_s_at & $\overline{1} .888585$ & 0.00172782 & $\overline{1} \cdot 18$ & 0.00337368 \\
\hline CCNB2 & Cyclin B2 & 202705_at & $\overline{1} .1595288$ & 0.04481641 & $\overline{1.43}$ & 0.00690167 \\
\hline CDKN1C & Cyclin-dependent kinase inhibitor $1 \mathrm{C}$ & 213348_at & $\overline{1} \cdot 3070001$ & 0.00646845 & $\overline{1.19}$ & 0.04085004 \\
\hline CENPA & Centromere protein A & 204962_s_at & $\overline{2} .1527643$ & 0.04419247 & -1.2 & 0.01221934 \\
\hline CEP76 & Centrosomal protein 76 & 52285_f_at & $\overline{1} .2023041$ & 0.00843916 & $\overline{1} \cdot 18$ & 0.00192199 \\
\hline CPOX & Coproporphyrinogen oxidase & 204172_at & $\overline{1} .0987262$ & 0.02304834 & $\overline{2} .47$ & 0.00275945 \\
\hline ENPP4 & $\begin{array}{l}\text { Ectonucleotide } \\
\text { pyrophosphatase/phosphodiesterase } \\
4\end{array}$ & 204161_s_at & $\overline{1} .8863298$ & 0.01127334 & -1.8 & 0.00230219 \\
\hline NCAM1 & Neural cell adhesion molecule 1 & 209968_s_at & $\overline{2} .1606266$ & 0.00608607 & $\overline{1} .39$ & 0.00440039 \\
\hline NEK2 & NIMA-related kinase 2 & 204641_at & $\overline{2} .4662128$ & 0.01606756 & $\overline{1} .73$ & 0.00514136 \\
\hline RHAG & Rh-associated glycoprotein & 206145_at & $\overline{2} .4662496$ & 0.00254827 & $\overline{2} .67$ & 0.01323244 \\
\hline RHOBTB1 & Rho-related BTB domain-containing 1 & 212651_at & -1.21743 & 0.01193424 & $\overline{1} .05$ & 0.0108552 \\
\hline SDAD1 & SDA1 domain-containing 1 & 218607_s_at & $\overline{1} .3541992$ & 0.00680884 & $\overline{1} \cdot 68$ & 0.00547458 \\
\hline SLC35F6 & Solute carrier family 35 member F6 & 204962_s_at & $\overline{2} .1527643$ & 0.04419247 & -1.2 & 0.01221934 \\
\hline TOP2A & Topoisomerase (DNA) II alpha & 201292_at & $\overline{1} .7960199$ & 0.00205856 & $\overline{1} .89$ & 0.00030621 \\
\hline TTK & TTK protein kinase & 204822_at & $\overline{1} .3045337$ & 0.00430803 & $\overline{1.03}$ & 0.00196834 \\
\hline ZNF184 & Zinc finger protein 184 & 213452_at & $\overline{1} .0276901$ & 0.02369172 & $\overline{1.16}$ & 0.03112214 \\
\hline
\end{tabular}




\section{Construction Of Ppi Networks Of Common Degs}

PPI networks of common up- and downregulated DEGs are shown in Fig. 2. Upregulated DEGs had no relation to each other, whereas downregulated DEGs constructed a few low-degree PPI networks, such as ATP-binding cassette subfamily B member 6 (ABCB6), coproporphyrinogen oxidase (CPOX), cyclin B2 (CCNB2), cyclin-dependent kinase inhibitor 1C (CDKN1C), centromere protein A (CENPA), centrosomal protein 76 (CEP76), NIMA-related kinase 2 (NEK2), topoisomerase (DNA) II alpha (TOP2A), and TTK protein kinase (TTK).

\section{Upstream Regulators Of Dominant Common Biomarker Candidates}

Upstream regulators of common DEGs between CP and LBW, such as PRRC2A, TOP2A, NCAM1, and CACNA2D3, were revealed using IPA software.

In this study, upstream regulators of PRRC2A and CACNA2D3 showed inhibitory reactions, while those of TOA2A and NCAM1 showed inhibitory or active reactions (Table 8).

\section{Discussion}

$\mathrm{CP}$ is a multifactorial disease, and relations between $\mathrm{CP}$ and systemic diseases have gathered increasing attention. The association between CP and LBW was first reported by Offenbacher et al. [1]. Many epidemiological studies have reported that pregnant women with CP are several times more likely than women without CP to have a preterm LBW infant [5-22]. Additionally, some studies have found that treatment for periodontitis is effective for preventing LBW [45-48]. Those studies reported that CP was an important risk factor for LBW. Specifically, hormonal alterations during pregnancy can cause bacterial infections to progress into periodontitis [2-4,49]. Chronic inflammation with CP induces the production of some proinflammatory cytokines [50-52]. Moreover, molecular studies have reported increased placental expression of interleukin-1 beta (IL-1 beta), cyclooxygenase-2 (COX-2), vascular endothelial growth factor receptor (VEGFR1), and heat shock protein (HSP70) in patients with CP [53]. These inflammatory mediators cause uterine contraction and vasoconstriction, which lead to LBW [54].

However, conversely, some studies have reported finding no association between CP and preterm LBW, and that treatment for periodontitis had no effect on the prevention of LBW [55-66]. Furthermore, as LBW is related to numerous risk factors, such as the mother's age, onset of prenatal care, systemic diseases, previous LBW infants, complications during pregnancy, and term of delivery, CP may not be an important risk factor for LBW [23-27, 67]. Thus, the precise association between CP and LBW remains unclear.

In this study, we focused on common genetic factors and molecular interactions between CP and LBW by performing gene expression analyses with pooled datasets from the GEO database.

Microarray analysis is a powerful tool to identify new candidate genes involved in the gene expression profiling of multifactorial diseases. Gene expression profiling involves the comprehensive study of gene expression levels; these can be used to diagnose a disease or predict treatment effects. The NCBI GEO database is the largest public repository for highthroughput biological assays generated by the research community [35-44].

In addition, data sharing and the integration of pooled omics data for investigations of biomedical mechanisms and multifactorial disease relations have gained increasing attention. Using pooled microarray gene expression datasets from the GEO is a method that reduces high-throughput hybridization costs and compensates for insufficient amounts of mRNA sampling [32-34].

In this study, we analyzed microarray gene expression datasets from the GEO database to elucidate the association between $\mathrm{CP}$ and preterm LBW. Although the two datasets contain different experiment conditions, subjects, and diseases, the relation 
between common genetic factor and biological interaction candidates and multifactorial diseases such as CP and LBW may be elucidated as screening tools.

Common genetic factors, molecular pathways, genetic interactions, and biomarker candidates between CP and LBW were analyzed using DAVID, STRING, and IPA. DAVID is a web-accessible program that provides a comprehensive set of functional annotation tools for investigators to understand biological meanings behind large lists of given genes [68]. STRIG is a database of known and predicted PPIs of multiple proteins [69]. IPA is an application built on a large knowledge database acquired by curators. IPA is a powerful application for the discovery of upstream regulators and biomarker candidates with omics data such as microarray analysis that identifies new biomarkers within the context of biological systems [70, 71].

The aim of this study was to elucidate key genes and biological interactions between CP and LBW using bioinformatics analysis of microarray datasets in the GEO database.

We examined important common factors and their functions related to CP and LBW. The functions of the genes were considered while referring to the information in NCBI GEO database [72].

Our analysis of CP and LBW gene expression profiles identified three significantly upregulated DEGs and 20 significantly downregulated DEGs. The three upregulated DEGs had no significant relation with each other. Among the three upregulated DEGs, PRRC2A can be assumed to be associated with inflammation and immunity as it is localized in the vicinity of the genes for tumor necrosis factors alpha and beta [72] PRRC2A is associated with rheumatoid arthritis and the age at onset of insulindependent diabetes mellitus [72]. Some downregulated DEGs, such as CCNB2, CDKN1C, CENPA, CEP76, NEK2, TOP2A, and TTK, were found to be related to the cell cycle from the functional analysis of the BP and pathway databases. Based on the PPI networks, TOP2 had direct interactions with the downregulated DEGs: CCNB2, TTK, NEK2, and CENPA.

The results of the IPA biomarker analysis showed that interferon-induced protein with tetratricopeptide repeats 2 (IFIT2), TOP2A, activating transcription factor 6 (ATF6), TNF superfamily member 10 (TNFSF10), NCAM1, CACNA2D3, phosphoribosylglycinamide formyltransferase, phosphoribosylglycinamide synthetase, phosphoribosylaminoimidazole synthetase (GART), PRRC2A, and Pvt1 oncogene (PVT1) were common molecular biomarker candidates.

Based on the upstream regulator analysis, catenin beta 1 (CTNNB1) and interleukin-5 (IL-5) were found to be the upstream regulators suppressing PPRC2A, which is one of the upregulated DEGs. CTNNB1 is involved in the bonding of cell adhesion molecules, the homeostasis of living organisms, and intracellular messenger activity [72]. IL-5 is a hematopoietic cytokine that plays an important role in the differentiation, maturation, mobilization, and activation of neutrophils [72].

TOP2A, NCAM1, and CACNA2D3 were identified as common downregulated DEGs, while beta-estradiol, transforming growth factor beta 1 (TGFB1), trichostatin A, and decitabine were identified as common upstream regulators showing inhibitory reactions to TOP2A and NCAM1. Sirolimus was found to be an upstream regulator showing active reactions to TOP2A and NCAM1.

As for CACNA2D3, there is nothing in common upstream regulators with TOP2A and NCAM1. Adenylate denylate-cyclase activating polypeptide 1 (ADCYAP1), musculoaponeurotic fibrosarcoma oncogene homolog B (MAFB), achaete-scute homolog 1 (ASCL1), nuclear receptor subfamily 3 group C member 2 (NR3C2), and pancreas transcription factor 1 subunit alpha (PTF1A) were found to be active upstream regulators of CACNA2D3. ADCYAP1 is a transduction material, MAFB is involved in the differentiation of hematopoietic stem cells to monocytes and macrophages, ASCL1 is a transcription factor required when cells differentiate into neurons involved in the nuclear receptor of steroids, such as NR3C2 [72].

The results of this study revealed that PRRC2A, TOP2A, NCAM1, CACNA2D3, CTNNB1, IL5, ASCL1, NR3C2, ADCYAP1, and MAFB are genes commonly associated with CP and LBW, and that upstream regulators such as lipopolysaccharide and pregnancy-associated hormones are dominant regulators commonly associated with CP and LBW. These key genes and regulators are related to not only inflammation and immunity, but also the cell cycle, the bonding of cell adhesion molecules, intercellular messenger activity, the homeostasis of living organisms, and cell differentiation.

Page 10/18 
Previously reported genes and regulators related to both CP and LBW in the PubMed database are shown in Table 9. In this study, BCL2/adenovirus E1B $19 \mathrm{kDa}$ protein-interacting protein 3-like (BNIP3L) and cyclin dependent kinase inhibitor 1A (CDKN1A) were found to be activated upstream regulators of TOP2A. Beta-estradiol, CD24, erb-b2 receptor tyrosine kinase 2 (ERBB2), estrogen, lipopolysaccharide, peroxisome proliferator-activated receptor alpha (PPARA), TGFB1, and tretinoin are inhibited upstream regulators of TOP2A, while beta-estradiol, TGFB1, and tretinoin are common inhibited upstream regulators of TOP2A and NCAM1, and NCAM1 is a common downregulated DEG and biomarker. Many of the listed genes and regulators are related to cell generation, development, and organization. Some genes and regulators were found to be indirectly related to immunology and inflammation, while some hormones related to pregnancy and fetal growth were found to influence CP and LBW as upstream regulators. The pooled omics data microarray analysis carried out in this study revealed that several genes related to CP and LBW have functions relevant to cell morphology, organ morphology, and skeletal and muscular diseases, in addition to inflammation and immunity.

Table 8

Upstream regulators of dominant common biomarker candidates

\section{Table 8. Upstream regulators of dominant common biomarker candidates}

\begin{tabular}{|c|c|c|}
\hline $\begin{array}{l}\text { Target gene } \\
\text { (up- or } \\
\text { downregulated } \\
\text { DEG) }\end{array}$ & Upstream regulator & $\begin{array}{l}\text { Predicted } \\
\text { activation } \\
\text { state }\end{array}$ \\
\hline $\begin{array}{l}\text { PRRC2A } \\
\text { (upregulated } \\
\text { DEGs) }\end{array}$ & CTNNB1, IL5 & Inhibited \\
\hline \multirow[t]{2}{*}{$\begin{array}{l}\text { TOP2A } \\
\text { (downregulated } \\
\text { DEG) }\end{array}$} & $\begin{array}{l}\text { dexamethasone, TGFB1, beta-estradiol, estrogen, trichostatin A, diethylstilbestrol, IL6, } \\
\text { FGF2, NRG1, OSM, testosterone, MYOD1, RABL6, YAP1, E2F1, P38 MAPK, poly rl:rc- } \\
\text { RNA, lipopolysaccharide, BRD4, NR1H3, PPARA, EWSR1, FOXM1, ERBB2, decitabine, } \\
\text { CFS2, CD3, tretinoin, LLLGL2, CD24, ELAVL1, NSUN6, trans-hydroxytamoxifen, } \\
\text { raloxifene }\end{array}$ & Inhibited \\
\hline & $\begin{array}{l}\text { LY294002, mir-21, PD98059, TCF3, dexamethasone, sirolimus, CDKN1A, BNIP3L, JQ1, } \\
\text { KRAS, curcumin, } 26 \text { s Proteasome }\end{array}$ & Activated \\
\hline \multirow[t]{2}{*}{$\begin{array}{l}\text { NCAM1 } \\
\text { (downregulated } \\
\text { DEG) }\end{array}$} & $\begin{array}{l}\text { TGFB1, beta-estradiol, tretinoin, progesterone, CTNNB1, trichostatin A, EGF, MYC, IGF1, } \\
\text { bucladesine, WNT3A, NFkB (complex), JUN, BMP7, phytohemagglutinin, BMP4, OTX2, } \\
\text { BDNF, CD38, NEUROD1, PAX8, EPHB4, decitabine, SOX4, CUX1, TNF, Ngf, } \\
\text { monocrotaline }\end{array}$ & Inhibited \\
\hline & MYCN, sirolimus, NOG, miR-182-5p, KRAS, curcumin, mir-210 & Activated \\
\hline $\begin{array}{l}\text { CACNA2D3 } \\
\text { (downregulated } \\
\text { DEG) }\end{array}$ & ADCYAP1, MAFB, ASCL1, NR3C2, PTF1A & Inhibited \\
\hline
\end{tabular}


Table 9

Genes and regulators reported to be related to both CP and LBW (PubMed)

\begin{tabular}{|c|c|}
\hline Genes and regulators reported in previous studies & Relation in this study \\
\hline Beta-estradiol & Inhibits upstream regulators of TOP2A and NCAM1 \\
\hline BNIP3L & Activates upstream regulator of TOP2A \\
\hline \multicolumn{2}{|l|}{ Camptothecin } \\
\hline CD24 & Inhibits upstream regulator of TOP2A \\
\hline CDKN1A & Activates upstream regulator of TOP2A \\
\hline \multicolumn{2}{|l|}{ Cisplatin } \\
\hline \multicolumn{2}{|l|}{ CYP3A4 } \\
\hline \multicolumn{2}{|l|}{ Doxorubicin } \\
\hline ERBB2 & Inhibits upstream regulator of TOP2A \\
\hline \multicolumn{2}{|l|}{ ESR1 } \\
\hline Estrogen & Inhibits upstream regulator of TOP2A \\
\hline \multicolumn{2}{|l|}{ FAS } \\
\hline \multicolumn{2}{|l|}{ GNAS } \\
\hline \multicolumn{2}{|l|}{ HFE } \\
\hline \multicolumn{2}{|l|}{ L-dopa } \\
\hline Lipopolysaccharide & Inhibits upstream regulator of TOP2A \\
\hline \multicolumn{2}{|l|}{ MDM2 } \\
\hline mir-21 & Activates upstream regulator of TOP2A \\
\hline \multicolumn{2}{|l|}{ MTHFR } \\
\hline NCAM1 & Common downregulated gene, common biomarker \\
\hline PPARA & Inhibits upstream regulator of TOP2A \\
\hline \multicolumn{2}{|l|}{$\mathrm{Rb}$} \\
\hline \multicolumn{2}{|l|}{ Sos } \\
\hline TGFB1 & Inhibits upstream regulators of TOP2A and NCAM1 \\
\hline \multicolumn{2}{|l|}{ TP53 } \\
\hline Tretinoin & Inhibits upstream regulators of TOP2A and NCAM1 \\
\hline
\end{tabular}

\section{Conclusions}

Investigations on the relation between phenotype and gene expression levels are important to elucidate biological-related factors in various diseases. Using the integrated analysis of omics data, such as those from microarray mRNA expression datasets, enables DEGs, genetic networks, common biomarker candidates, and upstream regulators to be identified, which is important not only for prognosis, diagnosis, and medical treatment, but also for the elucidation of the molecular mechanisms of multifactorial diseases as screening tools. 
The results of this study suggest that PRRC2A, TOP2A, NCAM1, and CACNA2D3 may be important common key genes related to $C P$ and LBW. To our knowledge, this is the first study to report the relations between PPRC2A, TOP2A, and CACNA2D3 and $\mathrm{CP}$ and LBW. These key genes are related to the cell cycle, cell composition, erythrocyte function, and transport pathways for small molecules. Among the upstream regulators of key genes, hormones such as beta-estradiol, estrogen, and progesterone had indirect effects on inflammation and immunity, whereas others had direct effects.

Therefore, inflammation-related factors caused by CP may influence gene expression associated with fetal growth. Conversely, female hormones related to pregnancy may affect the progress and development of CP. These predicted molecular key genes obtained from bioinformatics analysis should be further validated in future experimental research.

\section{List Of Abbreviations}

ABCB6: ATP-binding cassette subfamily B member 6; ADCYAP1: Adenylate cyclase-activating polypeptide 1; ASCL1: Achaetescute homolog 1; ATF6: Activating transcription factor 6; BP: Biological process; CACNA2D3: Calcium channel, voltagedependent, alpha 2/delta subunit 3; CCNB2: Cyclin B2; CDKN1C: Cyclin-dependent kinase inhibitor 1C; CENPA: Centromere protein A; CEP76: Centrosomal protein 76; COX-2: Cyclooxygenase-2; CP: Chronic periodontitis; CPOX: Coproporphyrinogen oxidase; CTNNB1: Catenin beta 1; DAVID: Database for Annotation Visualization and Integrated Discovery; DEGs: Differentially expressed genes; ERBB2: erb-b2 receptor tyrosine kinase 2; Fc: Fold change; GART: Phosphoribosylglycinamide formyltransferase, phosphoribosylglycinamide synthetase, phosphoribosylaminoimidazole synthetase; GEO: Gene Expression Omnibus; GO: Gene ontology; HSP70: Heat shock protein; IFIT2: Interferon-induced protein with tetratricopeptide repeats 2; IL-1 beta: Interleukin-1 beta; IL-5: Interleukin-5; IPA: Ingenuity Pathway Analysis; KEGG: Kyoto Encyclopedia of Genes and Genomes; LBW: Low birth weight; MAFB: Musculoaponeurotic fibrosarcoma oncogene homolog B; NCAM1: Neural cell adhesion molecule 1; NCBI: the National Center for Biotechnology Information; NEK2: NIMA-related kinase 2; NR3C2: Nuclear receptor subfamily 3 group $\mathrm{C}$ member 2; PPARA: peroxisome proliferator-activated receptor alpha; PPI: Protein-protein interaction; PRRC2A: Proline-rich coiled-coil 2A; PTF1A: pancreas transcription factor 1 subunit alpha; PVT1: Pvt1 oncogene; STRING: Search Tool for the Retrieval of Interacting Genes; TGFB1: Transforming growth factor beta 1; TOP2A: Topoisomerase (DNA) II alpha; TNFSF10: Tumor necrosis factor superfamily member 10; TTK: TTK protein kinase; VEGFR1: Vascular endothelial growth factor receptor 1

\section{Declarations}

\section{Ethics approval and consent to participate}

Not applicable.

\section{Consent for publication}

Not applicable.

\section{Availability of data and materials}

The datasets generated and analyzed in this study are available in the GEO datasets repository at https://www.ncbi.nlm.nih.gov/gds.

\section{Competing interests}

The authors declare that they have no competing interests.

\section{Funding}

Not applicable. 


\section{Authors' contributions}

AS conceived this study, participated in the design, and performed the statistical analysis. TH, AN, and EK participated in the design and helped draft the manuscript. YN helped draft the manuscript. All authors read and approved the final manuscript.

\section{Acknowledgements}

Not applicable.

\section{References}

1. Offenbacher S, Katz V, Fertik G, Collins J, Boyd D, Maynor G, McKaig R, Beck J. Periodontal infection as a possible risk factor for preterm low birth weight. J Periodontol. 1996;67:1103-13.

2. Calixto NR, Alves CM, Abreu LM, Thomaz EB, Vidal FC, Filho IS, Lopes FF. Detection of periodontal pathogens in mothers of preterm birth and/or low weight. Med Oral Patol Oral Cir Bucal. 2019. doi:10.4317/medoral.23135.

3. Guo H, Ren H, Liang S, Ji Y, Jiang H, Zhang P, Du M. Phosphatidylinositol 3-Kinase/Akt signal pathway resists the apoptosis and inflammation in human extravillous trophoblasts induced by Porphyromonas gingivalis. Mol Immunol. 2018. doi:10.1016/j.molimm.2018.10.008.

4. Puertas A, Magan-Fernandez A, Blanc V, Revelles L, O'Valle F, Pozo E, León R, Mesa F. Association of periodontitis with preterm birth and low birth weight: a comprehensive review. J Matern Fetal Neonatal Med. 2018. doi:10.1080/14767058.2017.1293023.

5. Figuero E, Han YW, Furuichi Y. Periodontal diseases and adverse pregnancy outcomes: Mechanisms. Periodontol 2000. 2020; doi:10.1111/prd.12295.

6. Wazir SS, Arora P, Ghosh S, Bhagat V, Khurana S, Mahanta S. Influence of maternal periodontal health as a risk factor for low-birth-weight infants in Terai population of Nepal. J Educ Health Promot. 2019. doi:10.4103/jehp.jehp_408_18.

7. Gesase N, Miranda-Rius J, Brunet-Llobet L, Lahor-Soler E, Mahande MJ, Masenga G. The association between periodontal disease and adverse pregnancy outcomes in Northern Tanzania: a cross-sectional study. Afr Health Sci. 2018. doi:10.4314/ahs.v18i3.18.

8. Meqa K, Dragidella F, Disha M, Sllamniku-Dalipi Z. The Association between Periodontal Disease and Preterm Low Birthweight in Kosovo. Acta Stomatol Croat. 2017. doi:10.15644/asc51/1/4.

9. Turton M, Africa CWJ. Further evidence for periodontal disease as a risk indicator for adverse pregnancy outcomes. Int Dent J. 2017. doi:10.1111/idj.12274.

10. Reza KM, Hamissi JH, Naeini SR, Karimi M. The Relationship Between Maternal Periodontal Status of and Preterm and Low Birth Weight Infants in Iran: A Case Control Study. Glob J Health Sci. 2015. doi:10.5539/gjhs.v8n5p184.

11. Govindaraju P, Venugopal S, Shivakumar MA, Sethuraman S, Ramaiah SK, Mukundan S. Maternal periodontal disease and preterm birth: A case-control study. J Indian Soc Periodontol. 2015. doi:10.4103/0972-124X.164751.

12. Parihar AS, Katoch V, Rajguru SA, Rajpoot N, Singh P, Wakhle S. Periodontal Disease: A Possible Risk-Factor for Adverse Pregnancy Outcome. J Int Oral Health. 2015;7:137-42.

13. Wang YL, Liou JD, Pan WL. Association between maternal periodontal disease and preterm delivery and low birth weight. Taiwan J Obstet Gynecol. 2013. doi:10.1016/j.tjog.2013.01.011.

14. Takeuchi N, Ekuni D, Irie K, Furuta M, Tomofuji T, Morita M, Watanabe T. Relationship between periodontal inflammation and fetal growth in pregnant women: a cross-sectional study. Arch Gynecol Obstet. 2013. doi:10.1007/s00404-012-26604.

15. Wandera M, Astrøm AN, Okullo I, Tumwine JK. Determinants of periodontal health in pregnant women and association with infants' anthropometric status: a prospective cohort study from Eastern Uganda. BMC Pregnancy Childbirth. 2012. doi:10.1186/1471-2393-12-90.

Page $14 / 18$ 
16. Corbella S, Taschieri S, Francetti L, De Siena F, Del Fabbro M. Periodontal disease as a risk factor for adverse pregnancy outcomes: a systematic review and meta-analysis of case-control studies. Odontology. 2012. doi:10.1007/s10266-0110036-z.

17. Agueda A, Ramón JM, Manau C, Guerrero A, Echeverría JJ. Periodontal disease as a risk factor for adverse pregnancy outcomes: aprospective cohort study. J Clin Periodontol. 2008;35:16-22.

18. Tucker R. Periodontitis and pregnancy. J R Soc Health. 2006;126:24-7.

19. Radnai M, Gorzó I, Urbán E, Eller J, Novák T, Pál A. Possible association between mother's periodontal status and preterm delivery. J Clin Periodontol. 2006;33:791-6.

20. Radnai M, Gorzó I, Nagy E, Urbán E, Novák T, Pál A. A possible association between preterm birth and early periodontitis. A pilot study. J Clin Periodontol. 2004;31:736-41.

21. Hasegawa K, Furuichi Y, Shimotsu A, Nakamura M, Yoshinaga M, Kamitomo M, Hatae M, Maruyama I, Izumi Y. Associations between systemic status, periodontal status, serum cytokine levels, and delivery outcomes in pregnant women with a diagnosis of threatened premature labor. J Periodontol. 2003;74:1764-70.

22. Krejci CB, Bissada NF. Women's health issues and their relationship to periodontitis. J Am Dent Assoc. 2002;133:323-9.

23. Krüger MSDM, Casarin RP, Pinto GDS, Pappen FG, Camargo MBJ, Correa FOB, Romano AR. Maternal periodontal disease and adverse perinatal outcomes: is there an association? A hospital-based case-control study. J Matern Fetal Neonatal Med. 2019. doi:10.1080/14767058.2018.1464554.

24. Fogacci MF, Cardoso EOC, Barbirato DDS, de Carvalho DP, Sansone C. No association between periodontitis and preterm low birth weight: a case-control study. Arch Gynecol Obstet. 2018. doi:10.1007/s00404-017-4556-9.

25. Vettore MV, Leal Md, Leão AT, da Silva AM, Lamarca GA, Sheiham A. The relationship between periodontitis and preterm low birthweight. J Dent Res. 2008;87:73-8.

26. Noack B, Klingenberg J, Weigelt J, Hoffmann T. Periodontal status and preterm low birth weight: a case control study. J Periodontal Res. 2005;40:339-45.

27. Davenport ES, Williams CE, Sterne JA, Murad S, Sivapathasundram V, Curtis MA. Maternal periodontal disease and preterm low birthweight: case-control study. J Dent Res. 2002;81:313-8.

28. Manrique-Corredor EJ, Orozco-Beltran D, Lopez-Pineda A, Quesada JA, Gil-Guillen VF, Carratala-Munuera C. Maternal periodontitis and preterm birth: Systematic review and meta-analysis. Community Dent Oral Epidemiol. 2019. doi:10.1111/cdoe.12450.

29. Daalderop LA, Wieland BV, Tomsin K, Reyes L, Kramer BW, Vanterpool SF, Been JV. Periodontal Disease and Pregnancy Outcomes: Overview of Systematic Reviews. JDR Clin Trans Res. 2018. doi:10.1177/2380084417731097.

30. Ren H, Du M. Role of Maternal Periodontitis in Preterm Birth. Front Immunol. 2017. doi:10.3389/fimmu.2017.00139.

31. Teshome A, Yitayeh A. Relationship between periodontal disease and preterm low birth weight: systematic review. Pan Afr Med J. 2016;24:215.

32. Henrik R, Gerd N, Dirk K, Jens V, Tanja G, Martin B, Gérard L, Kaspar B, Norbert R. On the Relevance of Technical Variation Due to Building Pools in Microarray Experiments. BMC Genom. 2015. doi:10.1186/s12864-015-2055-6.

33. Zhang W, Carriquiry A, Nettleton D, Dekkers JC. Pooling mRNA in microarray experiments and its effect on power. Bioinformatics. 2007. doi:10.1093/bioinformatics/btm081.

34. $10.1073 /$ pnas.0500607102

Kendziorski C, Irizarry RA, Chen KS, Haag JD, Gould MN. On the utility of pooling biological samples in microarray experiments. Version 2. Proc Natl Acad Sci U S A. 2005; Mar 22; doi:10.1073/pnas.0500607102.

35. Tanya B, Stephen EW, Pierre L, Carlos E, Irene FK, Maxim T, Kimberly AM, Katherine HP, Patti MS, Michelle H, Andrey Y, Hyeseung L, Naigong Z, Cynthia LR, Nadezhda S, Sean D, Alexandra S. NCBI GEO: archive for functional genomics data sets-update. Nucleic Acids Res. 2013. doi:10.1093/nar/gks1193.

36. Stephen EW, Tanya B. Strategies to Explore Functional Genomics Data Sets in NCBI's GEO Database. Methods Mol Biol. 2012. doi:10.1007/978-1-61779-400-1_3.

Page 15/18 
37. $10.1093 /$ nar/gkq1184

Tanya B, Dennis BT, Stephen EW, Pierre L, Carlos E, Irene FK, Maxim T, Kimberly AM, Katherine HP, Patti MS, Rolf NM, Michelle H, Oluwabukunmi A, Andrey Y, Alexandra S. (2011) NCBI GEO: archive for functional genomics data sets-10 years on. Nucleic Acids Res 2011; doi:10.1093/nar/gkq1184.

38. Tanya B, Dennis BT, Stephen EW, Pierre L, Dmitry R, Carlos E, Irene FK, Alexandra S, Maxim T, Kimberly AM, Katherine HP, Patti MS, Rolf NM, Ron E. NCBI GEO: archive for high-throughput functional genomic data. Nucleic Acids Res. 2009. doi:10.1093/nar/gkn764.

39. Ron E, Tanya B. NCBI GEO standards and services for microarray data. Nat Biotechnol. 2006. doi:10.1038/nbt1206-1471.

40. Tanya B, Dennis BT, Stephen EW, Pierre L, Dmitry R, Carlos E, Irene FK, Alexandra S, Maxim T, Ron E. NCBI GEO: mining tens of millions of expression profiles-database and tools update. Nucleic Acids Res. 2007. doi:10.1093/nar/gkl887.

41. Tanya B, Ron E. Gene Expression Omnibus (GEO): Microarray data storage, submission, retrieval, and analysis. Methods Enzymol. 2006. doi:10.1016/S0076-6879(06)11019-8.

42. Tanya B, Ron E. Mining Microarray Data at NCBI's Gene Expression Omnibus (GEO). Methods Mol Biol. 2006. doi:10.1385/1-59745-097-9:175.

43. Tanya B, Tugba OS, Dennis BT, Stephen EW, Wing-Chi N, Pierre L, Dmitry R, Alex EL, Wataru F, Ron E. NCBI GEO: mining millions of expression profiles-database and tools. Nucleic Acids Res. 2005. doi:10.1093/nar/gki022.

44. Ron E, Michael D, Alex EL. Gene Expression Omnibus: NCBI gene expression and hybridization array data repository. Nucleic Acids Res. 2002;30:207-10.

45. Kim AJ, Lo AJ, Pullin DA, Thornton-Johnson DS, Karimbux NY. Scaling and root planing treatment for periodontitis to reduce preterm birth and low birth weight: a systematic review and meta-analysis of randomized controlled trials. J Periodontol. 2012. doi:10.1902/jop.2012.110636.

46. Radnai M, Pál A, Novák T, Urbán E, Eller J, Gorzó I. Benefits of periodontal therapy when preterm birth threatens. J Dent Res. 2009. doi:10.1177/0022034508330229.

47. Offenbacher S, Lin D, Strauss R, McKaig R, Irving J, Barros SP, Moss K, Barrow DA, Hefti A, Beck JD. Effects of periodontal therapy during pregnancy on periodontal status, biologic parameters, and pregnancy outcomes: a pilot study. J Periodontol. 2006;77:2011-24.

48. López NJ, Smith PC, Gutierrez J. Periodontal therapy may reduce the risk of preterm low birth weight in women with periodontal disease: a randomized controlled trial. J Periodontol. 2002;73:911-24.

49. Siristatidis C, Nisiotakis C, Zokaris N, Chrelias C, lakovidou H, Salamalekis E. Hormonal alterations in gum disease leading to preterm labor. Arch Gynecol Obstet. 2006;274:13-8.

50. Saini R, Saini S, Saini SR. Periodontitis. A risk for delivery of premature labor and low-birth-weightinfants. J Nat Sci Biol Med. 2010. doi:10.4103/0976-9668.71672.

51. Tucker R. Periodontitis and pregnancy. J R Soc Promot Health. 2006;126:24-7.

52. Konopka T, Rutkowska M, Hirnle L, Kopec W, Karolewska E. The secretion of prostaglandin E2 and interleukin 1-beta in women with periodontal diseases and preterm low-birth-weight. Bull Group Int Rech Sci Stomatol Odontol. 2003;45:18-28.

53. Pozo E, Mesa F, Ikram MH, Puertas A, Torrecillas-Martínez L, Ortega-Oller I, Magán-Fernández A, Rodríguez-Martínez MD, Padial-Molina M, Sánchez-Fernández E, Galindo-Moreno P, O'Valle F. Preterm birth and/or low birth weight are associated with periodontal disease and the increased placental immunohistochemical expression of inflammatory markers. Histol Histopathol. 2016. doi:10.14670/HH-11-671.

54. Offenbacher S, Jared HL, O'Reilly PG, Wells SR, Salvi GE, LawrenceHP, Socransky SS, Beck JD. Potential pathogenic mechanisms of periodontitis associated pregnancy complications. Ann Periodontol. 1998;3:233-50.

55. Chambrone L, Guglielmetti MR, Pannuti CM, Chambrone LA. Evidence grade associating periodontitis to preterm birth and/or low birth weight: I. A systematic review of prospective cohort studies. J Clin Periodontol. 2011. doi:10.1111/j.1600051X.2011.01761.X. 
56. Michalowicz BS, Gustafsson A, Thumbigere-Math V, Buhlin K. The effects of periodontal treatment on pregnancy outcomes. J Periodontol. 2013. doi:10.1902/jop.2013.1340014.

57. Boutin A, Demers S, Roberge S, Roy-Morency A, Chandad F, Bujold E. Treatment of periodontal disease and prevention of preterm birth: systematic review and meta-analysis. Am J Perinatol. 2013. doi:10.1055/s-0032-1329687.

58. Rosa MI, Pires PD, Medeiros LR, Edelweiss MI, Martínez-Mesa J. Periodontal disease treatment and risk of preterm birth: a systematic review and meta-analysis. Cad Saude Publica. 2012;28:1823-33.

59. Fogacci MF, Vettore MV, Leão AT. The effect of periodontal therapy on preterm low birth weight: a meta-analysis. Obstet Gynecol. 2011. doi:10.1097/AOG.0b013e3181fdebc0.

60. Chambrone L, Pannuti CM, Guglielmetti MR, Chambrone LA. Evidence grade associating periodontitis with preterm birth and/or low birthweight: II: a systematic review of randomized trials evaluating the effects of periodontal treatment. J Clin Periodontol. 2011. doi:10.1111/j.1600-051X.2011.01761.x.

61. Polyzos NP, Polyzos IP, Zavos A, Valachis A, Mauri D, Papanikolaou EG, Tzioras S, Weber D, Messinis IE. Obstetric outcomes after treatment of periodontal disease during pregnancy: systematic review and meta-analysis. BMJ. 2011. doi:10.1136/bmj.c7017.

62. Uppal A, Uppal S, Pinto A, Dutta M, Shrivatsa S, Dandolu V, Mupparapu M. The effectiveness of periodontal disease treatment during pregnancy in reducing the risk of experiencing preterm birth and low birth weight: a meta-analysis. J Am Dent Assoc. 2010;141:1423-34.

63. Macones GA, Parry S, Nelson DB, Strauss JF, Ludmir J, Cohen AW, Stamilio DM, Appleby D, Clothier B, Sammel MD, Jeffcoat M. Treatment of localized periodontal disease in pregnancy does not reduce the occurrence of preterm birth: results from the Periodontal Infections and Prematurity Study (PIPS). Am J Obstet Gynecol. 2010. doi:10.1016/j.ajog.2009.10.892.

64. Newnham JP, Newnham IA, Ball CM, Wright M, Pennell CE, Swain J, Doherty DA. Treatment of periodontal disease during pregnancy: a randomized controlled trial. Obstet Gynecol. 2009. doi:10.1097/AOG.0b013e3181c15b40.

65. Offenbacher S, Beck JD, Jared HL, Mauriello SM, Mendoza LC, Couper DJ, Stewart DD, Murtha AP, Cochran DL, Dudley DJ, Reddy MS, Geurs NC, Hauth JC. Effects of periodontal therapy on rate of preterm delivery: a randomized controlled trial. Maternal Oral Therapy to Reduce Obstetric Risk (MOTOR) Investigators. Obstet Gynecol. 2009. doi:10.1097/AOG.0b013e3181b1341f.

66. Michalowicz BS, Hodges JS, DiAngelis AJ, Lupo VR, Novak MJ, Ferguson JE, Buchanan W, Bofill J, Papapanou PN, Mitchell DA, Matseoane S, Tschida PA. OPT Study. Treatment of periodontal disease and the risk of preterm birth. N Engl J Med. 2006;355:1885-94.

67. Martínez-Martínez RE, Moreno-Castillo DF, Loyola-Rodríguez JP, Sánchez-Medrano AG, Miguel-Hernández JH, OlveraDelgado JH, Domínguez-Pérez RA. Association between periodontitis, periodontopathogens and preterm birth: is it real? Arch Gynecol Obstet. 2016. doi:10.1007/s00404-015-3945-1.

68. DAVID. https://david.ncifcrf.gov/. Accessed 1 May 2020.

69. STRING. https://string-db.org/. Accessed 1 May 2020.

70. Krämer A, Green J, Pollard J Jr, Tugendreich S. Causal analysis approaches in Ingenuity Pathway Analysis. Bioinformatics. 2014. doi:10.1093/bioinformatics/btt703.

71. https://digitalinsights.qiagen.com/products-overview/discovery-insights-portfolio/analysis-and-visualization/qiagen-ipa/. 72. NCBI Gene. https://www.ncbi.nlm.nih.gov/gene. Accessed 10 May 2020.

\section{Figures}




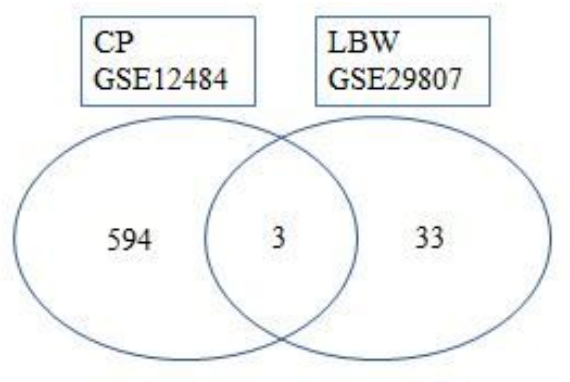

a

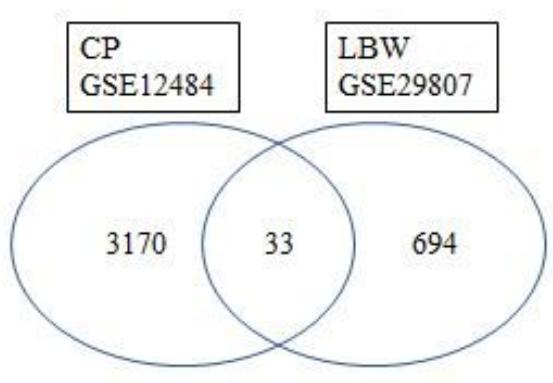

$\mathrm{b}$

\section{Figure 1}

Venn diagrams representing the overlaps between two GEO datasets. (a) the identification of upregulated DEGs. (b) The identification of downregulated DEGs.

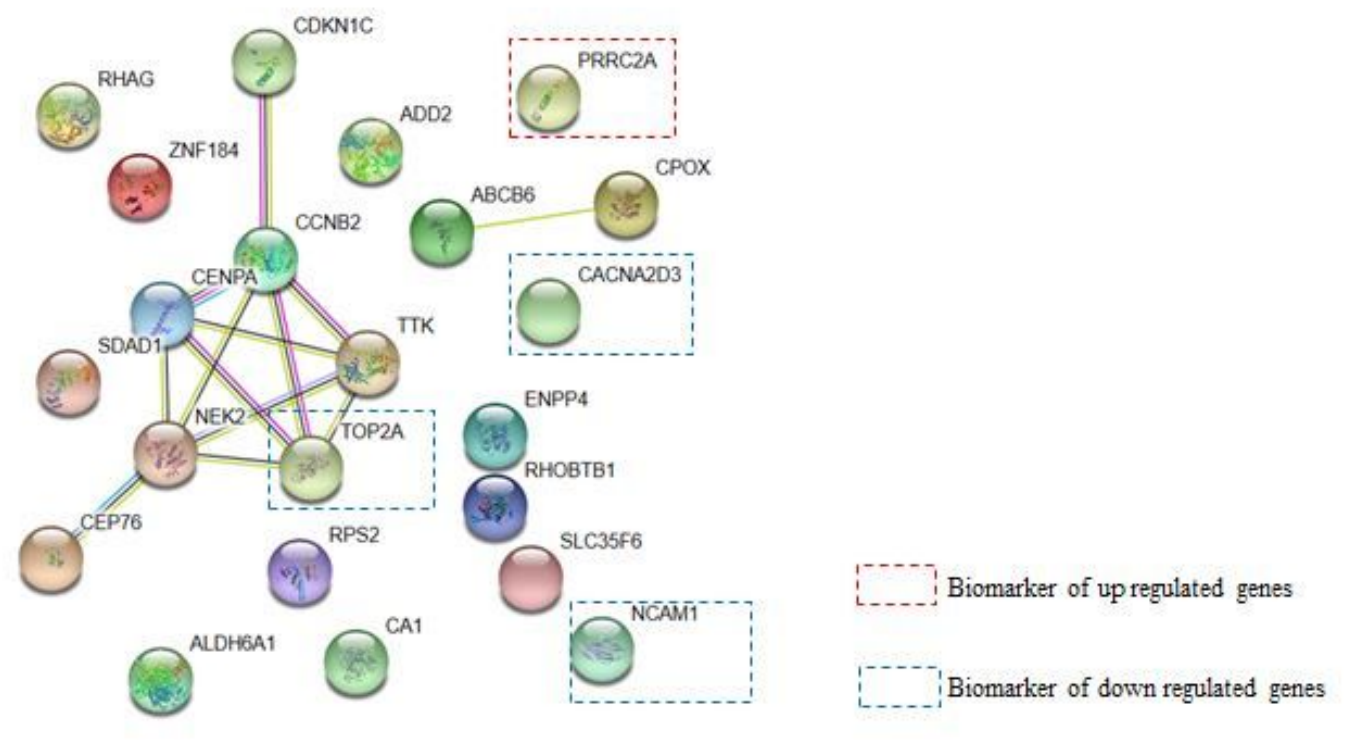

\section{Figure 2}

Up and down regulated genes and biomarkers RPA2 and PRRC2A are up regulated genes, ABCB6, ADD2, CA1, CACNA2D3, CCNB2, CDKN1C, CENPA, CEP76, CPOX, ENPP4, NCAM1, NEK2, RHAG, RHOBTB1, SDAD1, SLC35F6, TOP2, TTK and ZNF184 are down regulated genes. PRRC2A, CACNA2D3, NCAM1 and TOP2A are biomarker candidates. TOP2 had direct interaction CCNB2, TTK, NEK2, SDAD1 and CENPA which were down regulated genes. There is no protein-protein interaction among the up regulated genes such as RPS2 and PRRC2A. There are, however, some protein-protein interactions among the down regulated genes with low degree. 